\title{
Effects of the mixture of fenugreek seeds and Lespedeza cuneata extracts on testosterone synthesis in TM3 cells oxidative stressed with $\mathrm{H}_{2} \mathrm{O}_{2}$
}

\author{
Kyeong Soo Lee ${ }^{1} \cdot$ Eun Kyoung Lee ${ }^{1} \cdot{\text { Yoonhee } \text { Seo }^{2,3} \cdot \text { Soo Young Choe }}^{3}$ \\ 호로파와 야관문 복합추출물이 과산화수소로 산화적 스트레스가 가해진 \\ TM3 세포의 테스토스테론 합성에 미치는 영향
}

이경수 ${ }^{1}$ - 이은경 ${ }^{1} \cdot$ 서윤희 ${ }^{2,3} \cdot$ 최수영 ${ }^{3}$

Received: 9 June 2016 / Accepted: 3 August 2016 / Published Online: 31 December 2016

(C) The Korean Society for Applied Biological Chemistry 2016

\begin{abstract}
This study investigated the effects of a mixture of fenugreek seeds and Lespedeza cuneata extracts on testosterone synthesis in TM3 cells that were oxidatively stressed with $\mathrm{H}_{2} \mathrm{O}_{2}$. In order to oxidatively stress TM3 cells, the cells were treated with $50 \mu \mathrm{M}$ hydrogen peroxide for $4 \mathrm{hr}$ in serum-free media. Yagwanmun-horopa mixture (YHM) showed neither cytotoxicity nor increment of cell proliferation in the oxidatively stressed TM3 cells in any concentration. When the cells were treated with hydrogen peroxide, testosterone levels decreased, but the testosterone level was returned to that of the control level in the presence of YHM. In order to find out the reasons for the increase of testosterone, the expression of the genes involved in the synthesis or disintegration of testosterone. On the other hand, the levels of $3 \beta$-HSD4 and 17, 20-desmorase, which are involved in testosterone synthesis, were decreased through the use of hydrogen peroxide and were recovered through YHM treatment. Aromatase and $5 \alpha$-reductase2, which convert testosterone to
\end{abstract}

Soo Young Choe $(\bowtie)$

E-mail: schoe@chungbuk.ac.kr

${ }^{1}$ DuhanBIO Co. Ltd., Seoul 06774, Republic of Korea

${ }^{2}$ EBO Co., Ltd, Cheongju 28116, Republic of Korea

${ }^{3}$ Department of Biology, Chungbuk National University, Cheongju 28644, Republic of Korea

This is an Open Access article distributed under the terms of the Creative Commons Attribution Non-Commercial License (http://creativecommons. org/licenses/by-nc/3.0/) which permits unrestricted non-commercial use, distribution, and reproduction in any medium, provided the original work is properly cited. estradiol and dihydrotestosterone, respectively, were increased through the use of hydrogen peroxide, and were returned to control level through YHM treatment. These results suggest that YHM does not affect TM3 cell proliferation. However, YHM increases the expression of testosterone-synthesizing enzyme, which was decreased through oxidative stress, and decreases the expression of testosterone- converting enzyme, which was increased through oxidative stress. Therefore, it is reasonable that YHM has strong recovery activity on testosterone to normal level, even in the oxidatively stressed TM3 cells which mimics the andropause state.

Keywords Fenugreek seeds $\cdot$ Hydrogen peroxide $\cdot$ Lespedeza cuneata $\cdot$ Testosterone

\section{서 론}

정소내 Leydig 세포는 남성형질 및 정소 내에서의 정자형성을 촉진하는 테스토스테론의 주요 근원지이다(Zhang 등, 2008). 연 령과 비례하여 Leydig 세포가 감소하면 테스토스테론의 감소가 나타나며(Luo 등, 1996; Wang 등, 2002), 테스토스테론이 감소 하면 정자형성과정이 비활성화되고 근육의 강도가 약해지게 된 다(Sattler 등, 2011; Travison 등, 2011). 남자의 노화에 테스토 스테론 감소가 아주 주요한 비중을 가지고 있는데, 이러한 현 상을 남성갱년기 증상의 주요 원인으로 보고 있다. 남성갱년기 란 남성의 연령이 증가하면서 경험하게 되는 성적 본능, 활력 의 저하와 발기 장애, 근육량과 골밀도 감소, 수동적 태도 등의 
전형적인 증상들과 혈중 테스토스테론 농도가 저하되어 있는 임 상적, 생화학적 증후군을 의미한다(Bhasin 등, 2006; 2010; Nieschlag 등, 2006; Singh 2013). 남성갱년기에서 남성호르몬 부족을 보충하는 호르몬 보충요법의 유용성에 대한 연구들이 있 어 왔으나, 이 방법의 장기적인 효과와 안전성에 대한 논란이 있는 것도 사실이다(Gruenewald와 Matsumoto 2003; Muller 등, 2003). 따라서 남성호르몬 부족을 보완할 수 있는 보다 안전한 천연물에 대한 개발이 필요하게 되었다.

호로파(Fenugreek Seeds)는 알칼로이드, 단백질, 지방 등 약 40 여 가지의 성분을 함유하고 있는데(Duru 등, 2013), 예로부터 방광과 신장 등을 치료하는 데 사용되었다. 하지만 최근에는 남 성의 정력증진 및 몸 속의 혈당과 인슐린의 균형 유지와 체중 조절에도 효과가 있는 연구결과가 나타나고 있다(Kassem 등, 2006; Aswar 등, 2010). 야관문(Lespedeza cuneata)은 콩과의 싸리 속에 속하는 식물로, 한방에서 양기부족, 조루증을 비롯하 여 기침, 천식 등에 활용되어 왔다. 특히 야관문이 산화질소cGMP계를 통한 내피세포 의존성 혈관이완작용이 있고, 토끼의 음경해면체 평활근에 대한 이완효과가 있는 것으로 보고되어 심 혈관 질환과 발기부전의 치료에 활용할 수 있는 식물로 알려져 있다(Lee 등, 2012; Park과 Kim, 2013).

랫드를 이용한 동물시험에서(Lee 등, 2015) 호로파와 야관문 추출복합물이 테스토스테론의 양을 증가시키는 효능이 있는 것 으로 나타난 바, 본 연구에서는 이러한 테스토스테론의 증가에 관여하는 효소(3 $\beta$-HSD4, 17,20-desmorase) 및 감소에 관여하는 효소(aromatase, $5 \alpha$-Reductase2)의 발현에 실제로 호로파와 야 관문 추출혼합물이 어떠한 영향을 주는 지를 확인하고자 하였다.

\section{재료 및 방법}

\section{YHM 제조}

호로파 추출물은 호로파 종자를 $70 \%$ 에탄올로 $60 \sim 80{ }^{\circ} \mathrm{C}$ 에서 3 시간 동안 추출한 후 여과시켜 농축한 다음, $95{ }^{\circ} \mathrm{C}$ 에서 1 시간 동안 살균 후 분무건조기를 사용하여 분말로 제조하였다. 야관 문 추출물은 잎과 줄기를 사용하였으며 추출방법은 호로파 추 출물과 동일하게 실시하였다. 시험에 사용한 호로파 및 야관문 추출혼합물 중 호로파와 야관문 추출분말이 $8: 2$ 로 혼합한 것을 $\mathrm{YHM}$ 이라 명명하였다.

\section{세포배양 및 산화적 스트레스 유발}

Mus musculus (mouse)의 Leydig cell인 TM3 cell은 한국세포 주은행(Seoul, Korea)에서 구입하였다. $10 \%$ fetal bovine serum 및 antibiotics (Gibco BRL, Life Technologies Co., New York, NY, USA)가 포함된 DMEM 배지(Gibco BRL, Life Technologies Co.)에 3일에 한번씩 계대배양 하였다. 세포 는 $5 \% \mathrm{CO}_{2}$ 가 유지되는 $37{ }^{\circ} \mathrm{C}$ 배양기에서 배양하면서 사용하 였다. 세포를 분주하고 24시간 후, $50 \mu \mathrm{M}$ 과산화수소(SigmaAldrich, St. Louis, MO, USA)를 첨가한 serum free 배지에서 4시간 배양하는 방법으로 세포에 산화적 스트레스를 유발시키 고, 이후 시료가 농도 별로 포함된 배양배지에서 추가로 20 시 간 배양한 뒤 세포 및 배지를 수거하여 사용하였다.

\section{세포생존율 측정}

96well에 $7.5 \times 10^{3}$ cells $/ 0.1 \mathrm{~mL} / \mathrm{well}$ 이 되도록 세포를 분주하고 24 시간 후, $\mathrm{YHM}$ 이 농도별로 포함된 배양배지로 교환하여 24 시간 배양하였다. 과산화수소로 유도된 산화적 스트레스에서는 96well에 $1 \times 10^{4} \quad$ cells $/ 0.1 \mathrm{~mL} /$ well로 분주하였다. CCK-8 (Dojindo, Kamimashiki-gun, Kumamoto, Japan) $10 \mu \mathrm{L}$ 을 첨가 하고 $37{ }^{\circ} \mathrm{C} \mathrm{CO}$ 배양기에서 1시간 추가 배양한 후, ELISA leader (PowerWave XS, BioTek, Winooski, VT, USA)를 이용 하여 $450 \mathrm{~nm}$ 에서 흡광도를 측정하여 용매대조군 대비 세포생 존률을 구하여 시험에 사용할 농도를 결정하였다.

$$
\text { Survival rate }(\%)=\frac{\text { Absorbance }_{\text {sample }}-\text { Absorbance }_{\text {sample blank }}}{\text { Absorbance }_{\text {Vehicle }}-\text { Absorbance }_{\text {Vehicle blank }}}
$$

\section{Testosterone, aromatase 및 5 $\alpha$-reductase 2 측정}

호로파 추출물 및 야관문 추출물의 최적의 혼합비율을 결정하 기 위해 96 well에 $7.5 \times 10^{3}$ cells $/ 0.1 \mathrm{~mL} / \mathrm{well}$ 이 되도록 세포를 분주하고 24 시간 후 추출물 및 여러 가지 비율로 혼합한 추출 물이 포함된 배지로 교환하여 24시간 배양하고 배양배지를 수 거하여 테스토스테론 농도를 측정하였다. 과산화수소 스트레스 를 준 세포에서의 최적 혼합비율 추출물 $(\mathrm{YHM})$ 의 효능측정을 위해서는 6 well에 $3 \times 10^{5}$ cells $/ 3 \mathrm{~mL} / \mathrm{well}$ 로 분주하고 24 시간 후, 과산화수소가 $50 \mu \mathrm{M}$ 포함된 serum free 배지로 교환하였다. 4 시간 후 $\mathrm{YHM}$ 이 농도별로 포함된 배양배지로 교환하여 20시간 배양하고 배양배지를 수거하여 시험에 사용하였다. 테스토스테 론은 Enzo Life Sciences의 ELISA kit (Farmingdale, NY, USA)를 aromatase와 $5 \alpha$-reductase2의 농도는 EIAab Science의 kit (Wuhan, China)를 사용하여 측정하였다.

\section{Real-time PCR}

$60 \mathrm{~mm}$ dish에 $6.0 \times 10^{5}$ cells $/ 5 \mathrm{~mL}$ 로 분주하고 24 시간 후, 과산 화수소가 $50 \mu \mathrm{M}$ 포함된 serum free 배지로 교환하였다. 4시간 후 $\mathrm{YHM}$ 이 농도별로 포함된 배양배지로 교환하여 20시간 배양 하였다. easy-BLUE ${ }^{\mathrm{TM}}$ (iNtRON Biotechnology, Seongnam, Korea)를 이용해 RNA를 추출하여 spectrophotometer (UV2450, SHIMADZU, Nakagyo-ku, Kyoto, Japan)로 흡광도를 측 정하여 정량하여 사용하였다. 측정에 사용된 유전자 및 primer 는 Table 1 에 표시하였다. Total RNA $2 \mu \mathrm{g}$ 을 RevoScript ${ }^{\mathrm{TM}}$ Reverse Transcriptase premix kit (iNtRON Biotechnology)를 이용하여 총 부피 $20 \mu \mathrm{L}$ 로 반응하여 $\mathrm{cDNA}$ 로 합성하고, $\mathrm{SYBG}$ Green supermix (Bio-Rad, Hercules, CA, USA) $5 \mu \mathrm{L}$, cDNA $1 \mu \mathrm{L}$, 각각의 프라이머 $(10 \mathrm{pmol} / \mu \mathrm{L}) 1 \mu \mathrm{L}$ 그리고 $2 \mu \mathrm{L}$ 멸균증 류수를 섞어 Chromo $4^{\mathrm{TM}}$ Real-Time Detector (Bio-rad)로 다 음 조건으로 real time PCR을 수행하였다: 초기 변성은 $95^{\circ} \mathrm{C}$ 에서 30초, Annealing \& Extension은 $60^{\circ} \mathrm{C}$ 에서 30초 씩 40회 반복시켰다. 모든 반응은 housekeeping 유전자인 $\beta$-actin으로 보 정하고 과산화수소를 처리하지 않은 control을 기준으로 보정하 였다. 보정은 Vandesompele 등(2002)의 방법으로 계산하였다.

\section{통계처리}

모든 자료들은 평균과 표준편차로 나타내었으며 SPSS 프로그 
Table 1 Primers used for Real-time PCR analysis

\begin{tabular}{llll}
\hline \multicolumn{1}{c}{ Gene } & Accession No. & \multicolumn{1}{c}{ Forward $\left(5^{\prime} \rightarrow 3^{\prime}\right)$} & Reverse $\left(5^{\prime} \rightarrow 3^{\prime}\right)$ \\
\hline 3 $\beta$-HSD4 & L16919.1 & GTGATATGAAGAGGGAGAGGAC & AAGACAAGTTGGACAGAGTGT \\
17,20-Desmorase & NM_007809.3 & ACGCTCATCTTCAAGTCAGTAAT & GGTCTGTATGGTAGTCAGTATCG \\
Aromatase & NM_007810.3 & ACAATAAGATGTATGGAGAGTTCA & GCTTGAGGACTTGCTGATAA \\
$5 \alpha$-Reductase2 & NM_053188.2 & GCAAGCCTATTACCTGGTT & AGAAGACACCGACGCTAA \\
$\beta$-Actin & NM_007393.5 & AATCGTGCGTGACATCAA & GCTCGTTGCCAATAGTGA \\
\hline
\end{tabular}

램(ver. 21.0, SPSS INC., Chicago, IL, USA)을 이용하여 통 계해석을 실시하였다. One-way analysis of variation (ANOVA) 를 실시하여 유의성이 관찰되면 대조군과 유의차가 있는 시험 군을 확인하기 위해 Dunnett's t-test를 실시하였다(유의수준 양 측 $5 \%$ ).

\section{결과 및 고찰}

\section{YHM 추출혼합물 비율의 결정}

Leydig 세포인 TM3에서 호로파 및 야관문 추출물 처리 시 테 스토스테론 양을 얼마나 증가시킬 수 있는 지를 확인하고, 최 대한의 테스토스테론 증가를 얻기 위한 상기 두 추출물의 혼합 비율을 $5: 5,8: 2$ 그리고 $2: 8$ 로 다양하게 혼합하여 시험을 실시 하였다(Fig. 1). 시험에 사용한 각 시료들의 농도는 $20 \mu \mathrm{g} / \mathrm{mL}$ 로 통일하여 수행하였다. 호로파 또는 야관문 추출물 각각을 단독 으로 처리했을 때와, 호로파와 야관문 추출물을 비율별로 혼합 하여 처리한 결과를 비교하였을 때, 호로파와 야관문 추출물을 단독으로 처리한 경우보다, 호로파와 야관문 추출물의 혼합비율 이 8:2인 경우 테스토스테론 양이 가장 많이 증가되는 것으로 나타났다. 따라서 본 실험에서는 이러한 8:2 혼합물을 YHM이 라 명하고 실험에 사용하였다.

\section{YHM이 세포생존에 미치는 영향}

YHM이 TM3 세포에 미치는 독성을 평가하기 위하여 각 시료 를 농도별로 처리한 후 용매대조군(vehicle) 대비 세포의 생존 률을 구하였다. $\mathrm{YHM}$ 의 경우 $20 \mu \mathrm{g} / \mathrm{mL}$ 에서는 독성을 보이지

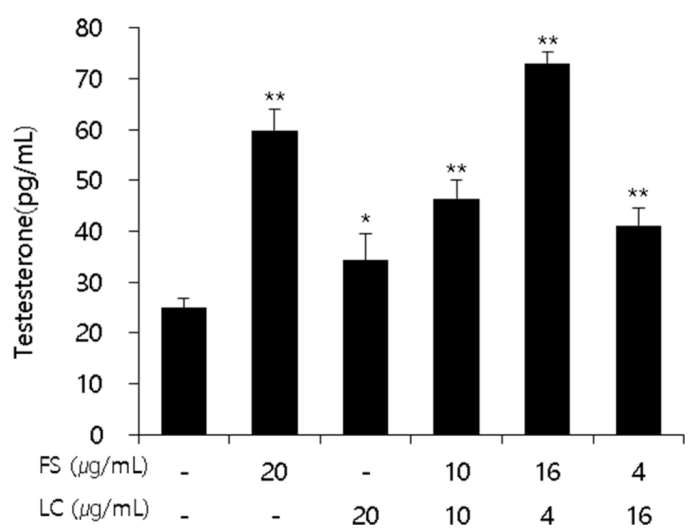

Fig. 1 Effect of Fenugreek seeds, Lespedeza cuneate on testosterone level in TM3 cell. The values are mean $\pm \mathrm{SD}, \mathrm{n}=3$. FS: Fenugreek seeds, LS: Lespedeza cuneate. Significant difference from vehicle group by Dunnet's t-test: ${ }^{*} p<0.05, * * p<0.01$
않았으며, $40 \mu \mathrm{g} / \mathrm{mL}$ 을 처리하였을 때 용매대조군 대비 $88.7 \pm 13.3 \%$ 의 세포 생존률을 보이고 $60,80,100 \mu \mathrm{g} / \mathrm{mL}$ 처리 하였을 때 각각 $83.4 \pm 11.7,80.2 \pm 14.5,72.4 \pm 13.9 \%$ 의 세포 생 존률을 보였다(Fig. 2A).

산화적 스트레스가 가해진 $\mathrm{TM} 3$ 세포생존에 시료가 미치는 영향을 측정하고자, TM3 세포에 과산화수소를 처리하였다. 과 산화수소의 처리 농도는 별도의 농도 설정시험을 통해 $50 \mu \mathrm{M}$ 로 설정하였다(data not shown). TM3 세포에 $50 \mu \mathrm{M}$ 과산화수 소를 4시간 처리한 후, 시료를 농도 별로 넣어준 배지로 교환 하여 20 시간 추가 배양하여 세포생존률을 측정하였다. 과산화 수소를 처리하지 않은 군에 비해 과산화수소만 4시간 처리한 군은 $77.4 \pm 5.6 \%$ 의 세포생존률을 보였으며, 여기에 YHM 10, $20,40 \mu \mathrm{g} / \mathrm{mL}$ 을 추가로 처리하였을 때에도 과산화수소만 처리 한 군과 비교했을 때 유사한 세포생존률을 보였다(Fig. 2B). 따 라서 YHM은 산화적 스트레스를 받은 TM3 세포의 증식에는 별다른 영향을 미치지 않는 것으로 나타났다.

\section{YHM이 테스토스테론 분비에 미치는 영향}

남성의 Leydig 세포는 중년이 지나면서 다양한 해로운 자극에 지속적으로 노출되어 점차 손상되어 간다. 이로 인해 나이가 먹 어감에 따라 생리적 기능이 점차 떨어지게 된다. 그 결과 테스 토스테론의 양도 점차 감소하여 남성갱년기의 증상이 나타나게 된다. 본 연구에서는 TM3 세포에 과산화수소를 처리함으로써 (Noh 등, 2012) 남성에서 나타나는 남성갱년기(andropause) 현 상을 유사하게 만들어 이의 개선 가능성을 보고자 하였다. 남 성갱년기에 대한 모델연구에서 남성갱년기의 원인으로 산화적 스트레스를 주요 원인중의 하나로 보고되고 있으며, 이러한 연 구에서 in vitro의 경우 과산화수소를 이용한 산화적 스트레스 모델이 많이 사용되고 왔다.

Tsai 등(2003)에 따르면 랫드의 leydig 세포에 과산화수소를 처리하면 테스토스테론의 방출이 감소하며, 이러한 결과는 과산 화수소 처리시 세포내에서 P450scc와 StAR 단백질 발현이 억 제되기 때문이라고 보고하였다. 이 두 단백질은 콜레스테롤을 pregnenolone으로 전환하며, pregnenolone은 progesterone, androstenedione, androstenediol로의 변환 단계를 거쳐, 종래에는 테스토스테론으로 변환된다. 현재까지 많은 연구에서 남성갱년 기 in vitro 모델의 경우, 과산화수소를 처리한 세포를 사용하여 연구가 진행되고 있다(Tsai 등 2003; Chang 등, 2008; Kim 등, 2012; Noh 등, 2012; Kim 등, 2015a; Kim 등 2015b).

$\mathrm{TM} 3$ 세포에 4시간동안 과산화수소를 처리하여 산화적 스트 레스를 준 경우, 테스토스테론의 양은 $33.3 \pm 3.8 \mathrm{pg} / \mathrm{mL}$ 으로, 과 산화수소를 처리하지 않은 세포의 $44.4 \pm 3.1 \mathrm{pg} / \mathrm{mL}$ 에 비해 25 $\%$ 감소하였다. YHM $10 \mu \mathrm{g} / \mathrm{mL}$ 을 추가로 처리하면 테스토스테 론의 양은 $30.0 \pm 2.1 \mathrm{pg} / \mathrm{mL}$ 으로 과산화수소만 처리한 군과 차이 

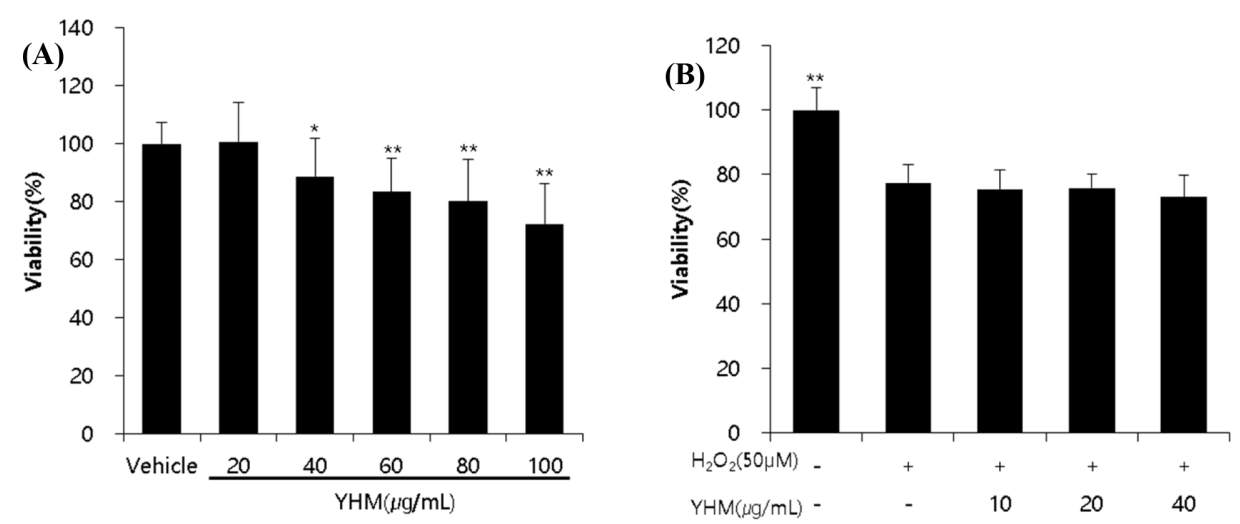

Fig. 2 Effect of YHM on cell viability in TM3 cells. (A) TM3 cells were treated with YHM(20,40,60, 80, 100 $\mu \mathrm{g} / \mathrm{mL})$ and (B) TM3 cell were treated with hydrogen peroxide $(50 \mu \mathrm{M})$ for 4 hours, and replaced with vehicle or medium containing the YHM was incubated for 20 hours. The values are mean $\pm \mathrm{SD}, \mathrm{n}=3$, (A) Significant difference from vehicle group by Dunnet's t-test: ${ }^{*} p<0.05,{ }^{* *} p<0.01$. (B) Significant difference from hydrogen peroxide only group by Dunnet's t-test: ${ }^{* *} p<0.01$

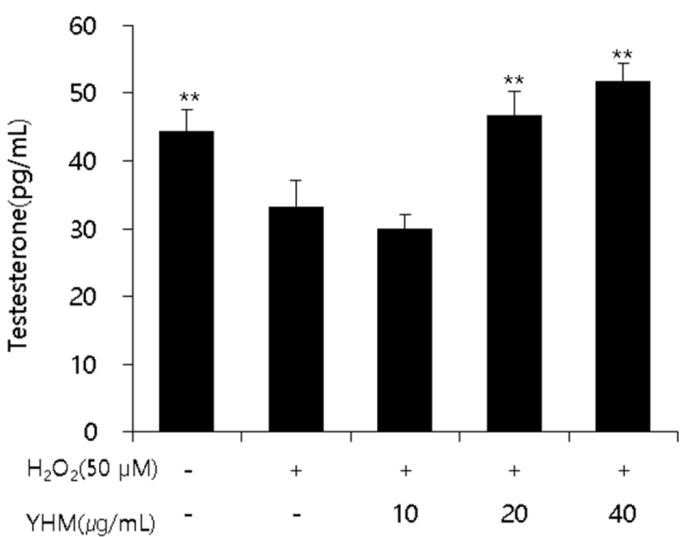

Fig. 3 Effect of YHM on testosterone level in hydrogen peroxide treated $\mathrm{TM} 3$ cell. The values are mean $\pm \mathrm{SD}, \mathrm{n}=3$. Significant difference from hydrogen peroxide only group by Dunnet's t-test: ${ }^{* *} p<0.01$

가 없었으나, $\mathrm{YHM}$ 을 $20,40 \mu \mathrm{g} / \mathrm{mL}$ 으로 농도를 높여 처리하면 $46.69 \pm 3.6,51.85 \pm 2.5 \mathrm{pg} / \mathrm{mL}$ 으로 높아져 control 세포에서의 양 과 비슷하거나 증가되는 것으로 나타났다(Fig. 3). 이러한 결과 는 TM3 세포에서 산화적 스트레스에 의해 감소된 테스토스테 론을 $\mathrm{YHM}$ 이 정상으로 회복시킬 수 있음을 보여주는 것인데, 이러한 결과는 남성갱년기 모델 세포에서 $\mathrm{YHM}$ 이 저하된 테스 토스테론 양의 회복 개선에 효과가 있음을 시사한다고 볼 수 있다.

YHM이 테스토스테론 합성과 관련된 유전자 발현에 미치는 영향 산화적 스트레스로 인해 감소된 테스토스테론 분비가 YHM 처 리 시 다시 정상상태로 회복되는 결과(Fig. 3)에 관여하는 효소 를 확인하기 위해, 테스토스테론 합성에 관여하는 유전자들의 발현을 real-time PCR로 확인하였다. Pregenenolone과 androstenediol을 progesterone과 테스토스테론으로 변환시키는 $3 \beta-$ $\mathrm{HSD} 4$ 는 과산화수소를 처리하였을 때 control에 비해 $46 \%$ 가 감 소하였다. 반면 $3 \beta-\mathrm{HSD} 4$ 의 발현은 $\mathrm{YHM}$ 을 $20 \mu \mathrm{g} / \mathrm{mL}$ 처리하 였을 때 control 수준으로 회복되고 $40 \mu \mathrm{g} / \mathrm{mL}$ 을 처리하면 control에 비해 1.9배까지 증가하였다(Fig. 4A). 또한 17-OH progesterone를 dehydroepiandrosterone (DHEA)과 androstenediol 로 변환시키는 17,20-desmorase의 경우 과산화수소를 처리하였 을 때 control에 비해 $30 \%$ 감소하였는데, YHM을 $20 \mu \mathrm{g} / \mathrm{mL}$ 처리하면 control 수준으로 회복되고 $40 \mu \mathrm{g} / \mathrm{mL}$ 을 처리하면 control에 비해 1.7배까지 증가하였다(Fig. 4B).

이러한 결과는 Fig. 3에서 산화적 스트레스에 의해 감소되었 던 테스토스테론이 $\mathrm{YHM}$ 처리 시 다시 증가하여 정상수준 이 상으로 회복된 이유를 잘 설명해주고 있다. 즉 산화적 스트레 스로 인해 발현이 감소되었던 테스토스테론 합성 유전자들이 YHM에 의해 그 발현이 다시 왕성해질 수 있도록 해주는 역할 을 하고 있음을 의미하는 것이다.

YHM이 테스토스테론 분해에 관련된 유전자 발현에 미치는 영향 산화적 스트레스를 받은 TM3 세포에서 감소된 테스토스테론의 양을 $\mathrm{YHM}$ 이 다시 회복시킬 수 있는 가능성의 하나로, 테스토 스테론을 다른 물질로 전환시켜 테스토스테론의 양을 감소시키 는 효소에 대한 영향을 분석하였다. 본 연구에서는 테스토스테 론과 androstenedione를 estradiol로 분해하는 aromatase와 testosterone을 dihydrotestosterone (DHT)로 전환시키는 $5 \alpha-$ reductase2의 발현을 조사하였다. aromatase 유전자의 발현은 과 산화수소를 처리하였을 때 control 보다 2.8 배 증가되는데, $\mathrm{YHM}$ 을 $10,20,40 \mu \mathrm{g} / \mathrm{mL}$ 을 처리하면 과산화수소만 처리하였 을 때보다 $76.5,77.1,79.0 \%$ 감소하였다. 또한 control에 비해 서는 각각 $33.7,35.3,40.6 \%$ 감소하였다(Fig. $5 \mathrm{~A}$ ). 또한 aromatase 효소의 양은 산화적 스트레스를 주었을 경우 $549.5 \pm$ $56.0 \mathrm{pg} / \mathrm{mL}$ 로 control의 $295.4 \pm 76.8 \mathrm{pg} / \mathrm{mL}$ 보다 약 1.9 배 증가 하였다. 하지만 $\mathrm{YHM}$ 처리군에서는 과산화수소에 의해 증가된 aromatase의 양이 control 수준으로 감소하였다(Fig. 5C).

테스토스테론을 DHT로 전환시키는 $5 \alpha$-Reductase2의 경우, 과산화수소에 의해 mRNA의 발현이 control에 비해 2.7배 증가 한 반면 YHM을 $10,20,40 \mu \mathrm{g} / \mathrm{mL}$ 처리하였을 때는 과산화수 소만 처리하였을 때보다 각각 $46.2,60.6$ 그리고 $68.9 \%$ 감소하 였으며, $20,40 \mu \mathrm{g} / \mathrm{mL}$ 처리 시의 값은 control 수준으로 회복되 는 것으로 나타났다(Fig. $5 \mathrm{~B})$. 또한 $5 \alpha$-Reductase 2 효소의 양은 

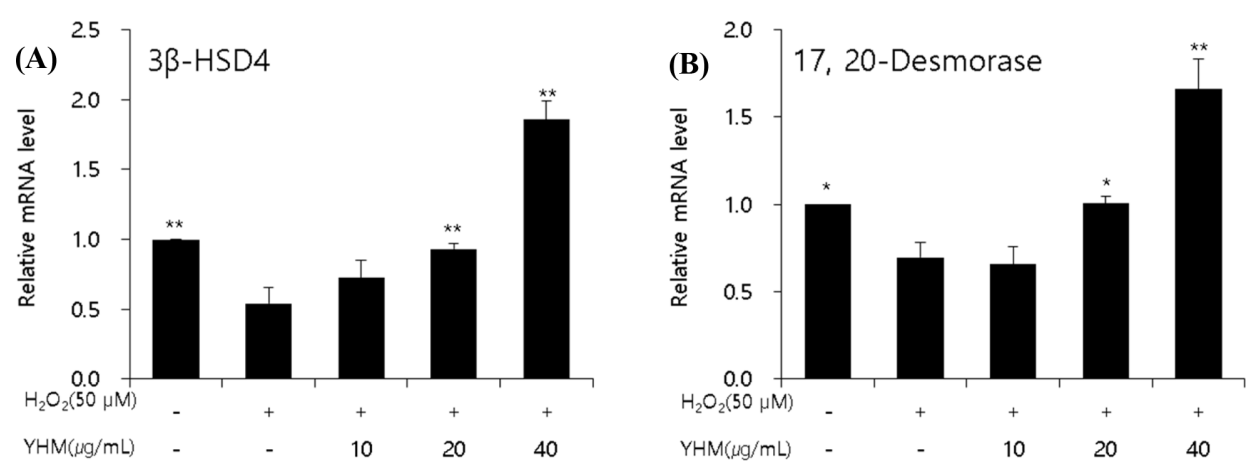

Fig. 4 Effect of YHM on expression of testosterone synthesis genes in hydrogen peroxide treated TM3 cell. (A) 3 $\beta$-HSD4 (B) 17, 20-desmorase. The values are mean $\pm \mathrm{SD}, \mathrm{n}=3$. Significant difference from hydrogen peroxide only group by Dunnet's t-test: ${ }^{*} p<0.05, * * p<0.01$
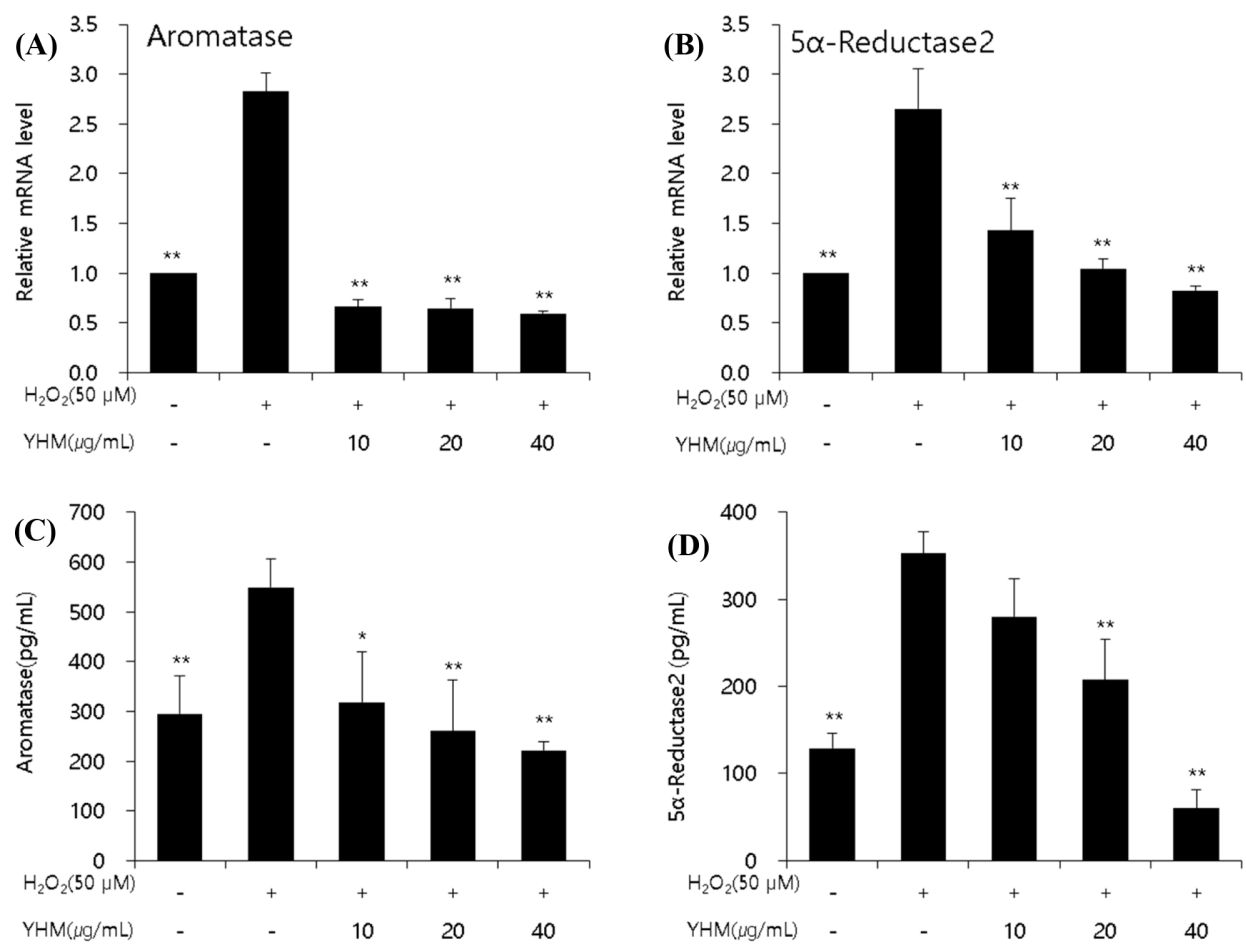

Fig. 5 Effect of YHM on expression of testosterone degradation genes and enzyme in hydrogen peroxide treated TM3 cell. (A, C) mRNA and protein level of aromatase, respectively. (B, D) mRNA and protein level of $5 \alpha$-reductase2, respectively. The values are mean \pm SD, $n=3$. Significant difference from hydrogen peroxide only group by Dunnet's t-test: ${ }^{*} p<0.05,{ }^{*} p<0.01$

과산화수소를 처리하였을 때 $352.9 \pm 24.4 \mathrm{pg} / \mathrm{mL}$ 로 control의 $129.0 \pm 17.5 \mathrm{pg} / \mathrm{mL}$ 에 비해 2.7배로 증가하였고, $\mathrm{YHM}$ 을 10,20 , $40 \mu \mathrm{g} / \mathrm{mL}$ 처리하였을 때는 각각 $280.0 \pm 43.7,207.9 \pm 46.6,60.4$ $\pm 21.0 \mathrm{pg} / \mathrm{mL}$ 로 농도 의존적으로 감소하였으며, 특히 $40 \mu \mathrm{g} / \mathrm{mL}$ 처리하였을 때는 control 보다 약 $50 \%$ 감소한 것으로 나타났 다(Fig. 5D).

이러한 결과는 Fig. 3에서 본 것처럼 스트레스에 의해 발현 이 감소된 테스토스테론 합성관련 유전자를 $\mathrm{YHM}$ 이 원상태로 회복시킬 뿐만 아니라, YHM은 스트레스에 의해 발현이 증가 된 테스토스테론 전환관련 유전자를 원상태로 다시 감소시키는 작용을 하여 양적으로 이상이 생긴 테스토스테론의 양을 원상 태로 되돌리는 탁월한 역할을 해주는 것으로 보인다.

최근 $\mathrm{YHM}$ 을 4주간 투여한 동물실험의 경우(Lee 등, 2015)
대조군에 비해 약 $30 \%$ 정도 혈중 테스토스테론이 증가한다는 보고가 있다. 상기의 논문에서는 $\mathrm{YHM}$ 에 의한 혈중 테스토스 테론 증가의 원인으로 호로파에 다량 함유되어 있는 것으로 알 려진 생리활성 성분인 diosgenin이 체내에서 DHEA로 전환되어 테스토스테론의 전구체로 작용할 수 있다는 보고(Murakami 등, 2000; Taylor 등, 2000; Sato와 Fujita 2014)에 기인한다고 추정하였으나, 본 연구의 결과에 의하면 $\mathrm{YHM}$ 이 테스토스테론 의 합성과 전환에 관여하는 유전자의 발현을 조절하는 요인으 로 보인다. 이 결과는 YHM 투여가 생체 내에서도 감소된 테 스토스테론의 분비를 다시 회복시킬 수 있음을 시사함으로써, 테스토스테론 감소로 인해 야기되는 남성갱년기의 증상 완화에 도움이 될 수 있을 것으로 판단된다. 


\section{초 록}

본 연구는 야관문과 호로파 복합추출물인 $\mathrm{YHM}$ 이 과산화수소 $\left(\mathrm{H}_{2} \mathrm{O}_{2}\right)$ 로 산화적스트레스를 가한 TM3 세포의 테스토스테론 발 현에 미치는 영향을 확인하고자 수행되었다. 세포독성 시험을 수행하여 $\mathrm{YHM}$ 의 경우 $40 \mu \mathrm{g} / \mathrm{mL}$ 을 최고 농도로 중농도 $20 \mu \mathrm{g} /$ $\mathrm{mL}$, 저농도 $10 \mu \mathrm{g} / \mathrm{mL}$ 처리군을 설정하였고, $\mathrm{TM} 3$ 세포에 산화 적 스트레스를 주기 위해서는, serum free 배지에 $50 \mu \mathrm{M}$ 의 과 산화수소를 4시간 동안 처리하였다. 산화적 스트레스가 가해진 TM3 세포에 YHM 시료를 처리하여 세포 생존률에 미치는 영 향을 평가하였을 때 모든 농도 처리군에서 세포증식이나 독성 이 없었다. 테스토스테론은 과산화수소를 처리하였을 때 감소하 였다가 YHM 시료를 처리하였을 때 control 수준으로 회복되거 나, control 보다 더 증가하였다. 또한 시료에 의한 테스토스테 론 양의 증가원인을 확인하기 위하여, 테스토스테론 합성 및 분 해에 관여하는 효소들의 발현량을 ELISA와 Real-time PCR을 통해 알아보았다. 테스토스테론 합성에 관여하는 3 $3-\mathrm{HSD} 4$ 와 17,20-desmorase는 과산화수소 처리 시 감소하였다가, $\mathrm{YHM}$ 을 처리하였을 때는 control 수준으로 회복하였다. 테스토스테론을 estradiol 및 dihydrotestosterone로 변환시키는 aromatase와 $5 \alpha$ reductase2는 과산화수소를 처리하였을 때 증가하였다가 $\mathrm{YHM}$ 시료를 처리하면 control 수준이나 그 이하로 감소하였다. 이 결 과들로 보았을 때 $\mathrm{YHM}$ 시료는 TM3 세포의 증식에는 영향을 미치지 못 하지만, 산화적 스트레스에 의해 감소된 테스토스테 론 합성 효소의 발현을 증가시키고, 반대로 증가되는 테스토스 테론 분해 효소의 발현은 감소시켜, 결국 산화적 스트레스에 의 해 저하된 테스토스테론의 양을 회복시키거나 증가시키는 효과 가 있는 것으로 판단된다.

Keywords 과산화수소 - 테스토스테론 - Fenugreek seeds · Lespedeza cuneata

\section{References}

Aswar U, Bodhankar SL, Mohan V, Thakurdesai PA (2010) Effect of furostanol glycosides from Trigonellafoenum graecum on the reproductive system of male albino rats. Phytother Res 24: 1482-1488

Bhasin S, Cunningham GR, Hayes FJ, Matsumoto AM, Snyder PJ, Swerdloff RS, Montori VM (2006) Testosterone therapy in adult men with androgen deficiency syndromes: An endocrine society clinical practice guideline. J Clin Endocr Metab 91: 1995-2010

Bhasin S, Cunningham GR, Hayes FJ, Matsumoto AM, Snyder PJ, Swerdloff RS, Montori VM (2010) Testosterone therapy in men with androgen deficiency syndromes: An endocrine society clinical practice guideline. J Clin Endocr Metab 95: 2536-2559

Chang MS, Kim WN, Yang WM, Kim HY, Oh JH, Park SK (2008) Cytoprotective effects of Morinda officinalis against hydrogen peroxideinduced oxidative stress in Leydig TM3 cells. Asian J Androl 10: 667674

Duru M, Erdoğan Z, Duru A, Kucukgul A, Duzguner V, Kaya DA, Şahin A (2013) Effect of seed powder of a herbal legume fenugreek (Trigonellafoenum graceum L.) on growth performance, body components, digestive parts, and blood parameters of broiler chicks. Pakistan J Zool 45: 1007-1014

Gruenewald DA, Matsumoto AM (2003) Testosterone supplementation therapy for older men: Potential benefits and risks. J Am Geriatr Soc 51: $101-115$

Kassem A, Al-Aghbari A, AL-Habori M, Al-Mamary M (2006) Evaluation of the potential antifertility effect of fenugreek seeds in male and female rabbits. Contraception 73: 301-306

Kim GY, Lee HG, Kim EJ (2015b) Effects of Extracts from Oja on Testosterone Synthesis in Leydig Cells. J Physiol \& Pathol Korean Med 29: 403-408

Kim JS, Hong MJ, Kim DR, Park EH, Chang MS, Park SK (2012) Study of Antioxidant Effects of Platycladi Semen on Male Reproductive cells. Kor J Herbology 27: 37-42

Kim SH, Kim DR, Chang MS, Park SK (2015a) Antioxidant effect of Woogyuyeum against hydrogen peroxide-induced oxidative stress in Leydig cells. Herbal Formula Science 23: 111-119

Lee JK, Kang DG, Lee HS (2012) Vascular relaxation induced by aqueous extract of Lespedeza cuneata via the NO-cGMP pathway. J Nat Med 66: $17-24$

Lee KS, Lee EK, Kim SY, Kim TH, Kim HP (2015) Effect of a Mixed Extract of Fenugreek Seeds and Lespedeza cuneata on Testosterone Deficiency Syndrome. Korean J Food SciTechnol 47: 492-498

Luo L, Chen H, Zirkin BR (1996) Are Leydig cell steroidogenic enzymes differentially regulated with aging? J Androl 17: 509-515

Muller M, van der Schouw YT, Thijssen JHH, Grobbee DE (2003) Endogenous sex hormones and cardiovascular disease in men. J Clin Endocr Metab 88: 5076-5086

Murakami T, Kishi A, Matsuda H, Yoshikawa M (2000) Medicinal foodstuffs XVII. Fenugreek seed. (3): Structures of new furostanol-type steroid saponins, trigoneosides Xa, Xb, XIb, XIIa, XIIb, and XIIIa, from the seeds of egyptianTrigonellafoenum graecum L. Chem Pharm Bull 48: 994-1000

Nieschlag E, Swerdloff R, Behre HM, Gooren LJ, Kaufman JM, Legros JJ, Lunenfeld B, Morley JE, Schulman C, Wang C, Weidner W, Wu FCW (2006) Investigation, treatment, and monitoring of late-onset hypogonadism in males: ISA, ISSAM, and EAU recommendations. J Androl 27: 135-137

Noh YH, Kim DH, Kim JY, Park J, Kim OH, Han D, Kim WY, Kim SS, Lee MY, Heo SH, Kim M, Lee WB, Jeong Y, Myung SC (2012) Improvement of andropause symptoms by dandelion and rooibos extract complex CRS-10 in aging male. Nutr Res Pract 6: 505-512

Park SY, Kim HH (2013) Effect of Lespedezea cuneata on the contraction of rabbit common carotid artery and corpus cavernosum. Korean J Orient Physiol Pathol 27: 809-817

Sato K, Fujita S, Iemitsu M (2014) Acute administration of diosgenin or dioscorea improves hyperglycemia with increases muscular steroidogenesis in STZ-induced type 1 diabetic rats. J Steroid Biochem 143: 152-159

Sattler F, Bhasin S, He J, Chou CP, Castaneda-Sceppa C, Yarasheski K, Binder E, Schroeder ET, Kawakubo M, Zhang A, Roubenoff R, Azen S (2011) Testosterone threshold levels and lean tissue mass targets needed to enhance skeletal muscle strength and function: the HORMA trial. J Gerontol A BiolSci Med Sci 66: 122-129

Singh P (2013) Andropause: Current concepts. Indian J EndocrinolMetab 17 (Suppl 3): S621-629

Taylor WG, Elder JL, Chang PR, Richards KW (2000) Microdetermination of diosgenin from fenugreek (Trigonellafoenum graecum) seeds. J Agr Food Chem 48: 5206-5210

Travison TG, Basaria S, Storer TW, Jette AM, Miciek R, Farwell WR, Choong K, Lakshman K, Mazer NA, Coviello AD, Knapp PE, Ulloor J, Zhang A, Brooks B, Nguyen AH, Eder R, LeBrasseur N, Elmi A, Appleman E, Hede-Brierley L, Bhasin G, Bhatia A, Lazzari A, Davis S, Ni P, Collins L, Bhasin S (2011) Clinical meaningfulness of the changes in muscle performance and physical function associated with testosterone administration in older men with mobility limitation. J Gerontol A BiolSci Med Sci 66: 1090-1099

Tsai SC, Lu CC, Lin CS, Wang PS (2003) Antisteroidogenic Actions of Hydrogen Peroxide on Rat Leydig Cells. J Cellul Biochem 90: 1276- 
1286

Vandesompele J, De Preter K, Pattyn F, Poppe B, Van Roy N, De Paepe A, Speleman F (2002) Accurate normalization of real-time quantitative RTPCR data by geometric averaging of multiple internal control genes. Genome Biology 3(7): research 0034.1-0034.11

Wang C, Hikim AS, Ferrini M, Bonavera JJ, Vernet D, Leung A, Lue YH,
Gonzalez-Cadavid NF, Swerdloff RS (2002) Male reproductive ageing: using the brown Norway rat as a model for man. Novartis Found Symp 242: 82-97

Zhang Y, Ge R, Hardy MP (2008) Androgen-forming stem Leydig cells: identification, function and therapeutic potential. Dis Markers 24: 277286 